The International Journal of

Sustainability

Education

Promoting Environmental and Cultural Awareness through Experiential Learning

JESSICA EVANS AND ELISSA GRAFF 
THE INTERNATIONAL JOURNAL OF SUSTAINABILITY EDUCATION

http://onsustainability.com/

First published in 2012 in Champaign, Illinois, USA

by Common Ground Publishing

University of Illinois Research Park

2001 South First St, Suite 202

Champaign, IL 61820 USA

www.CommonGroundPublishing.com

ISSN: 1832-2077

(C) 2012 (individual papers), the author(s)

(C) 2012 (selection and editorial matter) Common Ground

All rights reserved. Apart from fair dealing for the purposes of study, research, criticism or review as permitted under the applicable copyright legislation, no part of this work may be reproduced by any process without written permission from the publisher. For permissions and other inquiries, please contact <cg-support@commongroundpublishing.com>.

The International Journal of Sustainability Education is a peer-reviewed scholarly journal.

Typeset in CGScholar.

http://www.commongroundpublishing.com/software/ 


\title{
Promoting Environmental and Cultural Awareness through Experiential Learning
}

\author{
Jessica Evans, Lincoln Memorial University, TN, USA \\ Elissa Graff, Lincoln Memorial University, TN, USA
}

\begin{abstract}
According to the Association for Experiential Education, experiential education is "a philosophy and methodology in which educators purposefully engage with learners in direct experience and focused reflection in order to increase knowledge, develop skills, and clarify values." This form of learning can be used in a higher education setting in order to develop and nurture relationships, including "learner to self, learner to others, and learner to the world at large" (AEE). Using student narratives, this paper demonstrates how two groups of students enrolled at Lincoln Memorial University (Harrogate, Tennessee, USA) were able to develop greater environmental and cultural awareness of their own community by observing various environmental issues and cultural practices of Belizean communities. An art professor and a biology instructor taught a multidisciplinary course in March 2010 and March 2011. During the two 10-day courses, students were exposed to issues related to invasive species, pollution, as well as other environmental concerns. Furthermore, students were engaged in art activities that promoted environmental and cultural awareness, including art practices that focus on the use of natural resources. This paper will show that upon return to the home state of Tennessee, the knowledge gained by the students has had a sustained positive impact.
\end{abstract}

Keywords: Experiential Learning, Biology, Art, Environmental Awareness, Cultural Awareness, Belize, Interdisciplinary Education

\section{INTRODUCTION}

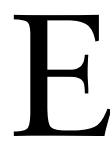

nvironmentally sustainable practices have become more commonplace in recent years with the modern environmental movement that encourages consumers to "go green." Environmentalists have been pushing for these practices as scientific evidence reveals an increase in the loss of Earth's biodiversity. The Millennium Ecosystem Assessment has compared extinction rates from the fossil record with extinction rates from the last several hundred years and has indicated that the current extinction rate is one hundred to one thousand times higher than past rates $(2005$, p. 14). This dramatic increase in the loss of biodiversity has been caused by habitat destruction, invasive species, pollution, increase of the human population, and overexploitation of the Earth's natural resources (Wright \& Boorse, 2011, pp. 139-146). The loss of biodiversity is especially disconcerting in the tropics, which contain at least half of all plant, animal, and microbial life, and is being cut down at a rate of five million to more than twenty million hectares per year (Cunningham \& Cunningham, 2011, p. 132).

Indigenous people are being displaced for many of the same reasons that biodiversity is disappearing, including habitat destruction in the tropics. These indigenous peoples have languages, cultures, religion, and racial communities distinct from the peoples of the countries they reside in (Cunningham and Cunningham, 2011, p. 10). Since its inception after World War II, the United Nations Educational, Scientific and Cultural Organization (UNESCO) has been respond-

The International Journal of Sustainability Education

Volume 1, 2012, http://onsustainability.com/, ISSN 1832-2077

(C) Common Ground, Jessica Evans, Elissa Graff, All Rights Reserved, Permissions:

cg-support@commongroundpublishing.com

A $C O M M O N$ G R O U N D 
ing to such concerns (UNESCO, 1995-2011). According to UNESCO, approximately 200 languages have disappeared in the past decade (Moseley, 2010). Since language is one aspect that makes a culture distinct, this loss is directly related to loss of culture. Furthermore "biological, linguistic, and cultural diversity are inseparable and mutually reinforcing, so when an indigenous language is lost, so too is traditional knowledge on how to maintain the worlds biological diversity and address climate change and other environmental challenges" (United Nations, 2008, para. 2).

UNESCO has expanded its mission to include the preservation of cultural diversity in both tangible culture, such as monuments and/or objects, and the intangible forms of culture that include "oral traditions, performing arts, social practices, rituals, festive events, and the skills and knowledge involved in craftsmanship" (UNESCO, 2003, p. 14). For intangible heritage, unlike an actual art object or heritage site, the value is the knowledge required to produce a craft. The notion of safeguarding and/or protecting this intangible heritage is to "ensure that the knowledge and skills associated with traditional artisanry are passed on to future generations so that crafts can continue to be produced within their communities, providing livelihoods to their makers and reflecting creativity" (UNESCO, Traditional Culture, para. 5). The UNESCO Question and Answer document on Intangible Cultural Heritage states that similar to apprenticeships, some sharing of methods that do not impinge on cultural secrets will actually promote cultural sustainability and broaden a shared knowledge base by allowing teachers to share some methods of artmaking with students. While biology and cultural studies, seem to be unrelated disciplines, they can be studied together in order to bring about greater awareness that promotes sustainable practices.

Jessica Evans, biology instructor at Lincoln Memorial University (LMU), and Elissa Graff, assistant professor of art at LMU, sought to promote environmental and cultural awareness by teaching an interdisciplinary, experiential education course. Their class focused on "direct experience and focused reflection in order to increase knowledge, develop skills and clarify values" (Association for Experiential Education, 2007-2010, para. 2). This course took two separate and different groups of students to the tropical country of Belize during the spring of 2010 and 2011. While there, students were engaged in biology lessons, art lessons, cultural lessons, and service learning activities. Students were exposed to different ecosystems found within Belize, were educated on environmental issues within these ecosystems, and were introduced to different cultures and cultural practices found in the country, including those of the Creole and Maya. This paper seeks to outline hands-on learning practices that were used to increase environmental and cultural awareness during the course. In addition, student narratives were used to show how interdisciplinary teaching methods achieved higher levels of environmental and cultural awareness.

\section{Experiential Learning}

Experience-based learning, as originally espoused by Dewey, is strongly proposed in all areas of education. Dewey (1934), in Art as Experience, describes an experience as having "pattern and structure" (p. 44). This implies that a measureable approach to experiential learning does exist. Dewey also compares experience to a river that flows from one part to another, each part being distinctive in and of itself, yet gaining from "what went before" (p. 36). The flow is continuous; it may grow or risk stagnation. "If a conclusion is reached, it is that of a movement of anticipation and cumulation, one that finally comes to conclusion. A 'conclusion' is no separate and independent thing; it is the consummation of a movement" (p. 38). Dewey's metaphor entails a more theoretical approach to learning by experience. It is this "river" of experience that allows one to learn. Many educators believe that "the learning context changes over time. It is never static or fixed" (Nygard, Hojlt, \& Hermansen, 2008, p. 35). Nygard, Hojlt, \& Hermansen (2008) are suggesting that if educators are truly being responsive to the needs of 
the student, then they are adapting curriculum to suit the learning processes and/or needs of the student (p. 35). How students learn is a burden on the field of education. Dewey (1933) says "that teaching is an art and the true teacher an artist" (p. 288).

In one example, Wilson, Murphy, Trautmann, and Makinster, (2009) present part of a curriculum development project entitled Crossing Boundaries "designed [as] an inquiry-based activity that introduces students to landscape change and potential impacts on associated biological communities" (p. 412). The authors, two from the Cornell Lab of Ornithology, one a middle school teacher, and the other a professor of education, utilized Google Earth and the United Nations Environmental Program to help develop students' skills in interpreting satellite imagery and their ability to infer potential causes of observed landscape change. The project was tracked by using completed worksheets and in-class presentations. The authors state the high range of worksheet scores and describe specific instances of lower achieving students' engagement as confirmation of success of the project.

Tonn, Ezzell, and Ogle (2010) describe a hands-on approach to teaching sustainable development in a Master of Science in Planning Program offered at the University of Tennessee (p. 144). Students meet with town citizens to brainstorm ideas that help the community achieve their sustainability goals (Tonn, Ezzell, \& Ogle, 2010). Then, the students research and prepare an action plan and, in workshop form, present their ideas back to the community (Tonn, Ezzell, $\&$ Ogle, 2010, p. 148). Tonn, Ezzell, and Ogle (2010) surveyed approximately sixty graduate students who confirmed they gained confidence in the real-world experience of co-planning productive change as well as in the public speaking arena of presenting to communities ( $\mathrm{p}$. 151). Actual work in the field, which ultimately helped the rural locales in East Tennessee, is a proactive offshoot of the experiential education definition.

Other curriculum designs that combine experiential methods with service learning components have had successful results. Much of the impetus for the inclusion for service projects in higher education comes as a response to Ernest Boyer's article, Creating the New American College, published in The Chronicle of Higher Education on March 9, 1994. Boyer, who served as U.S. Commissioner of Education from 1977 to 1979 and President of the Carnegie Foundation for the Advancement of Teaching from 1979 until his death in 1995, continues to be one of the most respected voices in the American Education system. His point of view essay asks how higher education can improve the national condition and deal with the present social, economic, and civic problems. He specifically calls for colleges and universities to remain true to their mission statements which include commitments to "not just teaching and research, but service too-a commitment that was never more needed that it is today" (Boyer, 1994, para. 10).

\section{Pre Field Experience}

The LMU course was designed to give students from rural Appalachia a hands-on learning experience of an environment and culture different from their own. Lincoln Memorial University (LMU) is located in Harrogate, Tennessee, where Tennessee, Kentucky, and Virginia meet at the Cumberland Gap, approximately fifty-five miles north of Knoxville, Tennessee. The university has more than eighteen hundred undergraduate students, who are mostly from the region (Lincoln Memorial University, 2012, para. 5). According to Appalachian Regional Commission (ARC) 2012 data, Claiborne County, Tennessee, where LMU's main campus is located, is designated as at-risk. ARC has labeled the areas surrounding LMU, both Bell County, Kentucky and Lee County, Virginia, as distressed, based on averages that are compared nationally using "three economic indicators-three-year average unemployment rate, per capita market income, and poverty rate" (Appalachian Regional Commission, 2012, para. 1). The ARC's economic classification for the region helps to explain why many of LMU's students have never been out of the country, some have never flown on a plane, and a few have never left the tri-state area. As a result of limited exposure to areas outside of the region, LMU students are often unaware 
of environmental and cultural issues that occur in regions other than their own. Offering a course that focused on ecosystems and cultures outside of Appalachia, Evans and Graff hoped to raise student awareness regarding twenty-first century global concerns.

Throughout both spring semesters, Evans and Graff met weekly with the classes. During these meetings, Evans discussed the characteristics of the different ecosystems the students would encounter, including tropical rainforest, pine savannah, and coral reef. She also gave a summary of the flora and fauna found within these ecosystems. Graff covered Maya history, specifically in reference to the sites the trip would include. She also discussed the recent resurgence of Maya craft in the culture and how this is improving the local economy. Throsby (2006) notes the relationship between creative and environmental conditions and refers to both as "capital" which has been inherited (p. 4). He further explains that both natural and cultural systems require future generations' maintenance for sustainability (Throsby, 2006, 4).

Additionally, both Evans and Graff discussed class expectations, including an explanation of student grades. In order to complete the course, students were required to keep a field journal with both art and biology components. The biology component included species identification while the art component included cultural engagement reflections. Lastly, students were told they would be required to complete a final art project once they returned to Tennessee. This project was deliberately left open for the students to self-design based on either their individual strengths (i.e.-artistic ability for the creation of a painting) or interests (i.e.-wildlife studies student might create photographic essay on the preservation of the Ceiba tree) (Graff \& Evans, 2012, para. 7).

\section{The Field Experience-Environmental Observations}

Though there were some minor changes between the 2010 and 2011 field experience, the overall trip outline remained the same. Both years the group visited a Maya ruin-Xuantunich in 2010, and Lamanai in 2011. At each ruin, students learned about the history of the Maya people and observed the artistic components and architecture of the ruins. Students also received lessons on the native flora and fauna of the region. They were taught the medicinal properties of many of the plants, and learned how these plants were, and still are, used by the Maya. For example, student $\mathrm{M}$, one of the students on the 2010 field experience, had been suffering from a stomach ailment. After speaking with our guide, she was able to experience the medicinal properties of one of the indigenous plants firsthand. M wrote in her journal "Percy told me the 'jungle' cure for my [stomach] disease." She learned how to remove a small section of bark from a gumbo limbo tree, dry it out, and then boil it for twenty minutes. She then drank this "tea" with noticeably improved results.

Another highlight of the course included an experience in the Sapodilla Cayes. In order to get to Hunting Caye, where the group stayed, they departed from Monkey River with three local, Creole small skiff boat captains who transported the group to their destination ninety minutes away. Student H, impressed by what the boat captains had to say on this journey, wrote "The [boat captains] gave us a talk and it is really sad what overfishing in Monkey River is causing. Most people that live in Monkey River were fisherman and because of the overfishing, it is causing men to lose jobs and food for their families." In talking to the captains, as H's response shows, the students were exposed to the devastation being caused by overfishing, which is something they might not ordinarily experience in Tennessee. Additionally, the students gained a better understanding of the importance of ecotourism, and how a local population can use it as a way to sustain a community that has lost a valuable natural resource.

Once on the island, the students listened to a lecture about reef structure and function and the impact of invasive organisms within these systems. After the lecture, the students snorkeled in the specific area that they had just investigated. They were able to identify corals and fish in the area, including the lionfish, an invasive species they had just studied. 
One of the other major components of the course included a trip to the Bladen Nature Reserve at the Belize Foundation for Research and Environmental Education (BFREE). This area is considered Belize's most "pristine protected rainforest" (SouthernBelize.com, 2012, para. 1). During their stay, the group went on hikes where they learned about the flora and fauna of this region and the adaptations that are required to live in such a wet environment. After one such hike, the group convened for a biology activity. The students were spaced along common paths in such a way that one student could not see the next one. They were told that they had to observe their surroundings for half an hour, and record anything significant. This exercise proved valuable since students were able to identify trees, shrubs, and flowers, note specific birdcalls, and note the behavior of leaf cutter ants or other small insect activity. Many of these students were able to identify more species in these thirty minutes in a tropical rainforest than they could in their native southern Appalachia.

\section{The Field Experience-Cultural Observations}

During the 2011 field experience, a service learning component was added to the stay at Hunting Caye. Students participated in a beach clean-up and learned that the majority of the trash found on the island was from the neighboring country of Guatemala. Through this exercise, students were able to understand that pollution travels outside of country borders, making it a global issue. Affected by this experience, student R wrote, "I'm glad I could help clean up the beach a little, I know we no more than scratched the surface of garbage a little bit, but I noticed the garbage pickup got some interesting conversations going. We discussed the numerous ways that we could reduce waste in the states. These included recycling, either for profit or just to recycle. The use of reusable as opposed to disposable bags at the store and the use of selfcheckout as a means to better insure the reusable bags are properly used so there is no need for disposable." After reading this, the professors realized that the students had learned to apply lessons learned in Belize to realistic issues and concerns that occur in the United States.

Another activity completed in the Bladen Nature Reserve required the students to collect native vegetation; strip vines for weaving and slice cohune nuts and transform them into jewelry. This activity accomplished many goals. First, the use of natural objects in art making created an experience that was very new and different for the students. Most were familiar with drawing, painting, or even ceramics, but gathering vegetation and making something usable or wearable was a revelation. Second, a strong connection between art and environment was made clear. And third, a respect for the Belizean craftsmaking culture was established.

The portion of the course that impacted the students the most was the homestay experience in a Maya village. During both years, the students were divided into small groups that went to the house of a local family. Each student had a different experience depending on his or her host family. Some students helped make tortillas from scratch; others went down to the river and watched how dishes were cleaned; and others took the children to the park. Student H, from the 2010 trip, wrote about the homestay experience stating, "We are now living with our host families. I am living with the C-family, who are the owners of the chocolate farm. This place is very different. I didn't realize how spoiled Americans really are until seeing how simple these people live and survive. We are sleeping on a dirt floor hut, all in the same room. I appreciate what I have at home a lot more." She went on to write about the chocolate making experience, which was something that was done as part of the Maya homestay during the 2010 trip: "Chocolate making was a lot of work. I have had a ton of fun today and this experience has really opened my eyes to how some people really live. I do think that these people are happier than the average American even though they do not have everything like we have." Student $\mathrm{N}$ from the 2011 trip wrote, "If there was one thing that I had to say impacted me the most on this trip, it would have to be the homestay component. I guess the mere fact of actually living with the culture was something that brought to me a genuine appreciation for its people." She 
continued with, "I thought it was also just wonderful to see how they do things, and what is really awesome is that when I got home, my grandfather told me that a lot of the things the Belizeans do are things we used to do, but have done away with. It made me realize that as Americans, we have become something that we have never intended to be. With our air conditioners, our washers and dryers, and our wasteful habits with our resources, we Americans have forgotten what it means to live and live well." Student N's comment showed that she was able to find similarities between the current Maya culture and the lost Southern Appalachian culture from her grandfather's time.

\section{Post Field Experience}

After the group returned to Tennessee, the students were given a few weeks to organize their journals and submit them. They were graded on the detail of the journals, including the amount of identified species, the habitats described, and the daily and overall reflections. From these reflections, Evans and Graff were able to evaluate the level of environmental and cultural awareness that students gained from this experiential education course.

Several students were impacted by the experiences that focused on environmental awareness. Student $S$ wrote, "Now, even when I'm back [in the United States] for 3 weeks already, if I see a bird I stare at it for a few good seconds, trying to figure out what it is." She continued with "This course is a good biology experience. You just notice things more, and you learn how to look for species and where and when, and you find yourself interested in searching for them. I don't think I've ever paid attention to so many species in my life, and I liked it." Student N wrote that after taking this course she "felt the need to conserve, conserve, conserve! (Energy, water, and everyday products)." She also went on to write that, "This trip did so much for me in so many different ways. ...I have begun to apply these experiences into my everyday life. I see how important it is to be out in nature. A lot of times I think we forget what is around us due to noise and being way to busy."

Though students gained an environmental awareness from this course, the artistic and cultural components proved to be just as important. After her stay in the Maya village, Student A wrote "I love the people here so much. Everyone is so friendly. And most do not have many of the things that I take for granted yet they are so happy with what they have. I love how family is so important here. The people seem to just cherish one another. I wish Americans (including myself) were more like that." Student M experienced similar feelings to Student A. She wrote, "This trip has taught me a lot. It gave me a new view on life. Like with my host family and the people on the island, they all showed me that some of the happiest people have the least amount of things. They don't worry about who has the newest or most expensive car or who has the biggest house. They worry about each other and surviving, living and learning as much as they can. They are truly some of the happiest people I have ever met.”

Some students were able to draw the connection between the environment and culture. Student J wrote, "Everywhere we went, the people were so nice and so concerned about their environment. It was really neat to see the diversity of culture, along with the vegetation and animals, which is so different from our own." After taking this course, Student R felt that "It is difficult to appreciate your situation (in terms of economics, education, society, etc.) until you have experienced another that varies from your own." She thought that by enrolling in this course "an LMU student would be made so much more aware of the diversity throughout the worlddiversity of culture and of lifestyle, but also of diversity of climate and ecosystems. This could in turn lead to a broader view of political and cultural events and the ability to compromise or at least look beyond one's own narrow experience." 


\section{Measuring the Success of Experiential Education}

Assessing outcomes from experiential practices is a challenge facing all implementers. While measuring devices, such as journals, narratives, and other tools are being successfully designed and implemented, there are variables that can skew results. Ewert and Sibthorp (2009) note that "participants, program designs, and individual program experiences" may each be a confounding variable (p. 377).

The concept of reflection is an important tool for assessing the experiential learning process. According to Andresen, Boud, and Cohen (2000), a key element of experience-based learning "is that learners analyse their experience by reflecting, evaluating and reconstructing it in order to draw meaning from it in the light of prior experience" (p. 225). Their definition of experiencebased learning and the criteria for its fulfillment connects heavily to David Kolb's work and his book, Experiential Learning (1984). Andresen, Boud, and Cohen (2000) quote Kolb: "Learning is the process whereby knowledge is created through the transformation of experience" (p. 226).

In addition, Janet Eyler (1999), in her book Where's the Learning in Service Learning? demonstrates the need to develop appropriate reflection techniques and pushes the educator to make the meaningful experience a valuable learning tool. "When reflection activities engage the learner in examining and analyzing the relationship between relevant, meaningful service and the interpretative template of a discipline, there is enormous potential for learning to broaden and deepen among academic, social, moral, personal, and civic dimensions" (Hatcher, Bringle, \& Muthiah, 2004, p. 39). In a 2009 paper commissioned by the Association of American Colleges and Universities (AAC\&U), Eyler makes the case "that experiential education can help students achieve intellectual goals commonly associated with liberal education" (page 2). She highlights four major goals in particular: "a deeper understanding of subject matter than is possible through classroom study alone, the capacity for critical thinking and application of knowledge in complex or ambiguous situations, the ability to engage in lifelong learning, including learning in the workplace, and the capacity for effective civic engagement" (Eyler, 2009, p. 2).

\section{Lessons Learned}

Through their course, Evans and Graff focused on raising awareness about environmental issues while also educating students on the preservation of cultural and artistic practices. Reflections from student journals indicated that by the conclusion of this course, students had a greater understanding of environmental issues than they had previously. Activities that focused on environmental issues allowed students to understand that environmental concerns are often global issues rather than just local ones. Additionally, students witnessed firsthand the greater levels of biodiversity that exist within the tropics. As they learned that many of the plant species found within this ecosystem contain medicinal properties, they were able to understand the importance of this biodiversity and the need to preserve it.

In addition, students became aware of cultures other than their own. They were able to draw connections between those cultures and ones that exist presently and historically in southern Appalachia. Students learned to appreciate a culture that does not rely on materialistic goods, which often require environmental degradation for their production, in order to be happy. As demonstrated in the field journals, the students benefitted immensely from the interdisciplinary experience. Before an individual can implement sustainable practices into their life, he or she must be aware of the underlying issues that require these practices in the first place. Awareness is often the first step towards developing and practicing sustainable values.

When considering the multitudes of learning styles and practices, and what will serve the needs of the student and the future of the world, requiring educators to be artists, like Dewey 
suggests, seems an understatement. Eyler (2009) reminds us that "experiential education blurs the line between theory and practice; theory lacks meaning outside of practice" (p. 28). Sibthorp, Schumann, Gookin, Baynes, Paisley, and Rathunde (2011) suggest the ultimate goal of experiential education is the development of life-long learners. Lastly, Huber and Hutchings (2004) state that "at the heart of liberal education lies the idea that learning should be greater than the sum of its parts" (p. 11). 


\section{REFERENCES}

Andresen, L., Boud, D., \& Cohen, R. (2000). Experience-based Learning. In G. Foley (Ed.) Understanding adult education and training ( $2^{\text {nd }}$ ed., pp. 225-239). Sydney, AU: Allen \& Unwin.

Appalachian Regional Commission. (2012). County Economic Status and Distressed Areas in Appalachia. Retrieved February 11, 2012, from http://www.arc.gov/appalachian_region/CountyEconomicStatusandDistressedAreasinAppalachia.asp

Appalachian Regional Commission. (2012). County Economic Status and Distressed Areas in Appalachia. [Data]. Retrieved February 11, 2012, from http://www.arc.gov/images/appregion/economic_statusFY2012/CountyEconomicStatusandDistressAreasFY2012DataTables.xls

Association for Experiential Education. (2007-2010). What is experiential education? Retrieved October 19, 2010, from http://www.aee.org/about/whatIsEE

Boyer, E. L. (1994, March 9). Creating the new American college. The Chronicle of Higher Education, p. A48. Retrieved from ProQuest Education Journals.

Cunningham, W. \& Cunningham, M. (2011). Principles of Environmental Science: Inquiry and applications. New York, NY. McGraw Hill.

Dewey, J. (1933). How we think. Boston, MA: Houghton Mifflin Company.

Dewey, J. (1934). Art as experience. New York, NY: Perigree Books.

Ewert, A., \& Sibthorp, J. Creating outcomes through experiential education: The challenge of confounding variables. Journal of Experiential Education, 31(3), 376-389. Retrieved from http://search.proquest.com.ezproxy.lmunet.edu/docview/274969892?accountid= 12101

Eyler, J. (2009, March). Effective practice and experiential education. Paper presented at the conference on Liberal Education and Effective Practice, Mosakowski Institute for Public Enterprise.

Eyler, J. (2009). The power of experiential education. Liberal Education, 24-31. Retrieved from http://search.proquest.com.ezproxy.lmunet.edu/docview/209817016? accountid $=12101$

Graff, E. and Evans, J. (2012). Experiential learning: Merging art with biology. The International Journal of Interdisciplinary Social Sciences, www.SocialSciences-Journal.com

Griset, O. L. (2010). Meet us outside! The Science Teacher, 40-46. Retrieved from http://search.proquest.com/docview/214621130?accountid=12101

Hatcher, J. A., Bringle, R. G., Muthiah, R. (2004). Designing effective reflections: What matters to service learning? Michigan Journal of Community Service Learning, 11(1), 38-46. Retrieved from http://hdl.handle.net/2027/spo.3239521.0011.104

Kolb, D. A. (1984). Chapter two: The process of experiential learning. In D. A. Kolb, Experiential learning: Experience as the source of learning and development (pp. 20-38). Englewood Cliffs: Prentice-Hall, Inc.

Lincoln Memorial University. (2012). Quick Facts. Retrieved February 11, 2012, from http://www.lmunet.edu/about/quickfacts.shtml

Millennium Ecosystem Assessment. (2005). Ecosystems and Human Well Being: Biodiversity Synthesis. Washington D.C. World Resources Institute.

Moseley, Christopher (Ed.). (2010). Atlas of the World's languages in danger. $3^{\text {rd }}$ ed. Paris: UNESCO Publishing. Online version: http://www.unesco.org/culture/en/endangeredlanguages/atlas

Nygaard, C., Hojlt, T., \& Hermansen, M. (2008). Learning-based curriculum development. Higher Education, 55, 33-50. doi: 10.1007/s10734-006-9036-2

SouthernBelize.com. (2012). Bladen Nature Reserve. Retrieved from http://www.southernbelize.com/ bladen.html 
Throsby, D. (2006). On the sustainability of cultural capital. Unpublished paper. Retrieved from http://www.econ.mq.edu.au/research/2005/cult_cap_throsby.pdf

Tonn, B., Ezzell, T., \& Ogle, E. (2010). Experiential learning and sustainable economic development in Appalachian communities: A teaching note. Journal of Appalachian Studies, $144-155$.

UNESCO. (2003). Intangible heritage domains. Retrieved from online version at http://www.unesco.org/culture/ich/index.php?lg=en\&pg=00057

UNESCO. (2003). Traditional craftsmanship. Retrieved from http://www.unesco.org/culture/ich/index.php?lg=en\&pg=00057

UNESCO. (1995-2011). The organization's history. Retrieved February 12, 2012 from http://www.unesco.org/new/en/unesco/about-us/who-we-are/history/

United Nations. (2008). Indigenous languages. Retrieved February 12, 2012 from http://www.un.org/esa/socdev/unpfii/documents/Factsheet_languages_FINAL.pdf

Wilson, C. R., Murphy, J., Trautmann, N. M., \& Makinster, J. G. (2009). From local to global: A birds-eye view of changing landscapes. The American Biology Teacher, 71, 412-417. Retrieved from Academic Search Premier, EBSCOhost.

Wright, R. \& Boorse, D. (2011). Environmental Science: Toward a Sustainable Future 11e. San Francisco, CA. Benjamin Cummings.

\section{ABOUT THE AUTHORS}

Jessica Evans: Lincoln Memorial University, USA

Elissa Graff: Elissa Graff obtained a Bachelor of Fine Arts from Miami University and a Master of Fine Arts from the University of Kansas. During six years of employment at Appalachian State University, she obtained her K-12 Art Teaching Certification. Now, she resides in the Cumberland Gap region of Southeastern Kentucky and is one of two professors of Visual Arts at Lincoln Memorial University. Being an avid hiker and runner has inspired her artwork and has deeply connected her to the landscape. Creating work from nature has motivated her to educate others on the need for both appreciation and preservation of our world. Recycling and/or reusing materials have become recurrent themes in both her art and her teaching. She is currently pursuing her doctorate focusing on engaging today's college student through the use of experiential practices. 
The International Journal of Sustainability Education is one of four thematically focused journals in the family of journals that support the Sustainability knowledge community-its journals, book series, conference, and online community. It is a section of The International Journal of Environmental, Cultural, Economic and Social Sustainability.

The journal explores teaching and learning about human relations to the environment. It also investigates community education and the challenge of raising public awareness about sustainability.

In addition to traditional scholarly papers, this journal invites presentations of practice-including documentation of curricular practices and exegeses analyzing the effects of those practices.

The International Journal of Sustainability Education is a peer-reviewed scholarly journal.

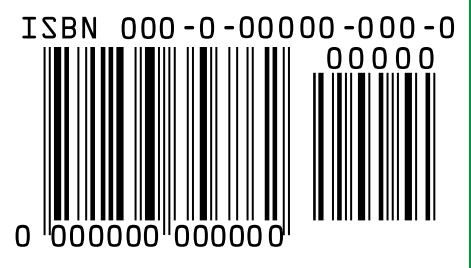

